\title{
Kolejny tom studiów nad Sokratesem
}

Livio Rossetti, Alessandro Stavru (eds.), Socratica 2008. Studies in Ancient Socratic Literature, Levante Editori, Bari 2010, ss. 353.

\section{FRANCESCA PENTASSUGLIO / Roma}

Książka stanowi zbiór tekstów przedstawionych podczas konferencji w Neapolu w dniach od 11 do 13 grudnia 2008 r. w Istituto Italiano per gli Studi Filosofici i poświęconych antycznej literaturze sokratejskiej. Po obszernym wstępie, w którym Livio Rossetti i Alessandro Stavru rozważają szczegółowo status quaestionis studiów sokratejskich aż do ostatnich publikacji (s. 11-55), następuje przedstawienie trzynastu wystąpień podzielonych na cztery jednostki tematyczne, które dotyczą kolejno pierwszej generacji sokratyków, Platona, Ksenofonta i Nachleben Sokratesa w antyku.

Pierwszą sekcję otwiera artykuł „I Socratici 'primi filosofi' e Socrate „primo filosofo” (s. 59-70), w którym Livio Rossetti rozważa stosowanie kategorii „filozofia” i „filozofowie” do myślicieli przedsokratejskich (tym samym tematom poświęcił Rossetti swój artykuł „L'invenzione della filosofia”, opublikowany w Bollettino della Società Filosofica Italiana $\mathrm{nr} 200 \mathrm{z}$ maja - sierpnia 2010, s. 3-16). Wskazując na rzadkie występowanie tych dwóch terminów aż do Vw. oraz na częste ich użycie w dekadach następujących po roku 399 przed Chr., autor przypisuje zasługę tę Sokratesowi i sokratykom, którzy jako pierwsi świadomie określali się mianem „filozofów”, tworząc w ten sposób właściwe sobie pojęcie filozofii jako umiłowania mądrości, a także zaznaczając swą odrębność od pierwszych physiologoi i podkreślając preferowaną przez nich wykładnię dialogiczną. Przyrównanie autorów Peri physeos do philosophoi, które się przyjęło za sprawą Arystotelesa, choć płynne było jeszcze w czasach Platona, nie wskazuje już na dialektykę (zetetykę) sokratejską, lecz oferuje jawne treści doktrynalne.

Kwestia konfliktu sokratyzmu z sofistyką badana jest przez Noburu Notomi, który sprowadza ją do platońskiej inwencji („Socrates versus Sophists: Plato’s invention?”, 
s. 71-88). Platon kładzie nacisk na napięcie między Sokratesem i sofistami, co stanowi część składową jego strategii obronnej i wynika z konieczności oddzielenia obrazu Sokratesa od form fałszywej mądrości reprezentowanej przez Sofistów. Taki wniosek bierze się z rozważenia dwóch porządków: z jednej strony nie da się ściśle oddzielić działalności sokratyków od Sofistów, a z drugiej - w świadectwie Ksenofonta nie ma wzmianki co do odrębnego statusu epistemologicznego filozofii i sofistyki.

W obrębie sokratyków „pierwszej generacji”, Aldo Brancacci rozważa Antystenesa, zwłaszcza jego myśl etyczną („Sull'etica di Antistene”, s. 89-117). Godna podkreślenia jest przy tym osnowa intelektualistyczna: sokratejskie zrównanie cnoty i wiedzy przechodzi u Antystenesa w głębszy związek moralności i poznania, od którego zależy inny istotny związek dialektyki i etyki, połączony z refleksją nad językiem. Myśl logiczno-dialektyczna i etyka bazują na tej samej dystynkcji pomiędzy oikeion i allotrion, czyli między tym, co człowiekowi jest właściwe, i tym, co jest mu obce. Nadaje to etyce pewną dwutorowość. W porównaniu z etyką stoicką adiaphoron nie ma bowiem znaczenia, a z perspektywy sokratejskiej rzeczy są allotria względem tego, co jest właściwe tylko człowiekowi - phronēsis.

Pierwszą sekcję zamyka tekst Domingo Plácido o Ajschinesie, w którym rozważa się specyfikę dialogów Alkibiades i Aspasia („Esquine de Esfeto: las contradicciones del socratismo", s. 119-133). Ajschines to postać kontrowersyjna: nauczał i tworzył mowy sądowe za opłatą, a zarabiał na sposób potępiany przez Sokratesa w Ekonomiku, co oddala go od kanonu platońskiego Sokratesa i stawia między sokratyzmem i sofistyką. Plácido tłumaczy to ubóstwem, jakie dotknęło Ajschinesa na tle stanu gospodarki wraz z końcem wojny peloponeskiej. Ajschines żył w społeczeństwie transformacji, w którym wpływ sokratyzmu ujawnił się poza środowiskami arystokratycznymi.

W pierwszym z czterech tekstów poświęconych Platonowi, „L'impossible autarcie du Socrate de Platon” (s. 137-158), Louis-André Dorion wychodzi od stwierdzenia, że Platon, inaczej niż Ksenofont, nigdy nie mówi expressis verbis o autarkii Sokratesa. Wynikało to z wyznawanego przezeń ideału ubóstwa oraz z silnych więzi przyjaźni cechujących jego Sokratesa, które składają się zarazem na chimeryczną samowystarczalność materialną ksenofontowego Sokratesa. Znaczący jest też brak autarkeia w Sympozjonie, gdzie występują dwa inne elementy triady etycznej Ksenofonta (kartēria i enkrateia). Właściwy tu paralelizm między Sokratesem, Erosem i filozofią stanowi przeszkodę w jego autarkii: to właśnie jako filozof Sokrates został skazany za nie-samowystarczalność intelektualną.

Na paradoksalnych treściach stanowisk platońskiego Sokratesa koncentruje się Walter Omar Kohan, analizując je w potrójnym wymiarze polityki, wiedzy i wychowania („La paradoja de enseñar y aprender”, s. 159-184). Autor skupia się na wychowawczym paradoksie: Sokrates podaje siebie za oudenos didaskalos, choć przyznaje się do uczniów, którzy podejmą jego misję wychowawczą. Oczywista jest tutaj żywiona przez Sokratesa chęć uwolnienia pedagogiki od trybu przekazu wiedzy właściwej w nauczaniu profesjonalnym, na rzecz metody uczącej problematyzować stan wiedzy i niewiedzy w nadaniu tej ostatniej waloru pozytywnego i twórczego. 
W eseju „Socrate e la conoscenza di sé: per una nuova lettura di Alc. I 133- a-c” (s. 185-210), Lidia Palumbo powraca do znanego miejsca w dialogu Platona, kontestując jego potoczną egzegezę, która wiąże motyw poznania siebie z odniesieniem się do innej duszy i takim jej odwzorowaniem, w którym każdy człowiek poznawać może duszę własną. Ta interpretacja, której tekst nie zawiera, powstaje w wyniku rozszerzenia analogii między okiem i duszą, która ogranicza się do wspólnego odniesienia do przykładu widzenia: nie jest tak, że dusza ma potrzebę odbicia się w innej, by dojrzeć samą siebie. $\mathrm{Z}$ drugiej zaś strony status dialogu u Platona nie wymaga ani wzajemności, ani konfrontacji z innym: w strukturze argumentacyjnej pytanie i odpowiedź mają swoją postać może ona wyrażać się w formie milczącej myśli czy dialogu duszy z sobą samą (Teajtet).

Ostatni wykład w tej sekcji: „Socrate tra golpe oligarchico e restaurazione democratica” (s. 211-224), zwraca uwagę na kontekst historyczny, czyli tło procesu Sokratesa, w celu zrozumienia którego należy odnieść się do dwóch istotnych wydarzeń w historii Aten. Uzgadniając antyczną historię z historią antycznej filozofii, dwaj autorzy, Gabriele Cornelli i André Leonardo Chevitarese, koncentrują się na ścisłej przynależności politycznej Sokratesa i jego bliskości z reżimem Trzydziestu, która to pozwala zrozumieć miejsce w Liście VII (325 b-c). Argumentują oni, iż jest to szczególna okoliczność, ponieważ Sokrates należał do obywateli, którzy nie podlegali ani wydaleniu, ani konfiskacie dóbr ze strony oligarchów. Bardziej czytelne okazują się tym samym motywacje polityczne, które legły u podstaw decyzji sądu w Atenach.

Kolejne dwa teksty poświęcone są Ksenofontowi i Sokratesowi z Memorabiliów. W „Xenophon's Socrates on Sophia and the Virtues” (s. 227-240) Donald Morrison zatrzymuje się nad problematyką sophia, ukazując zarazem oscylowanie Ksenofonta między doktryną jedności cnót (która przypomina analogiczne tezy sokratejskie w Protagorasie i Eutydemie) oraz ideą, dla której mądrość może być raz dobra, raz zła (która zdaje się im przeczyć). Proponowane rozstrzygnięcie sugeruje pewne przemyślenie związku między sophia i innymi cnotami: te bowiem jako typy różne od mądrości, nie są identyczne ani wzajemnie, ani względem samej sophia. Bez sprowadzenia do czystego genus, sophia zawiera w sobie różne cnoty jako stosowane w różnych dziedzinach tej samej wiedzy o dobru i pięknie, stając sie w ten sposób warunkiem wystarczającym, ale nie koniecznym dla ich posiadania.

Sokratesowi Ksenofonta poświęcony jest artykuł „Essere e apparire in Xen. Mem. III 10.1-8” (s. 241-276). Alessandro Stavru analizuje tutaj przedstawione u Ksenofonta konwersacje Sokratesa z malarzem Parrazjosem i rzeźbiarzem Klejtonem. Traktując je równolegle, wskazuje on na wspólną procedurę sokratejską, która dotyczy związku między tworzeniem artystycznym a tym, co nieprzedstawiane i niedostępne żadnej figuracji, tj. duszy. Badana jest więc rola phainesthai w różnych formach reprezentacji ujętej w miejscu, z którego wynika istota praktyki artystycznej - medium między widzialnym i niewidzialnym, co polega zarazem na tworzeniu pozoru. Tak odzyskany zostaje spekulatywny walor tego passusu, wbrew pozornemu brakowi precyzji językowej czy błędowi koncepcyjnemu. Ksenofont, daleki od epizodycznego wnikania w motywy artystyczne, zna i przepracowuje literaturę specjalistyczną pokrewną sztuce mimetycznej. 
Ostatnią sekcję otwiera tekst Michaela Erlera pt. „La parrhēsia da Socrate a Epicuro” (s. 279-298). Wychodząc od centralnej roli, jaką stanowi parrhēsia w szkole epikurejskiej, autor cofa się do Sokratesa jako „protoparresiasty filozoficznego”, aby następnie dojść do polityczno-demokratycznej genezy tego pojęcia. Przyswojenie terminu w filozoficznej konwersacji przechodzi przez dialogi platońskie, w których parrhēsia Sokratesa współżyje problematycznie z formami udawania i restrykcji poznania: tutaj eirōneia i parrhēsia zintegrowane są z pedagogiką filozoficzną w celu uniknięcia nieporozumień ze strony rozmówcy. Na zasadzie dozowania informacji względem odbiorcy powstaje dystans między Sokratesem i epikurejczykami, którzy wyznają niezrównaną szczerość nauki powszechnie zrozumiałej, odzyskując niejako okrężnie znaczenie parrhēsia w demokratycznej komunikacji.

Esej Graziano Ranocchia analizuje miejsce De Vitiis, w którym to Filodemos podaje obraz eirōn zawarty w De liberando a superbia Aristona (Il ritratto di Socrate nel De Superbia di Filodemo (PHerc. 10o8, coll. 21-23), s. 299-320). Stawia on tezę, że taki rys karykaturalny, pełen odniesień do Sokratesa, przynależy się in toto Arystonowi, który tożsamy był $\mathrm{z}$ historykiem Arystonem z Chios. Interpretację tę potwierdza radykalnie negatywna koncepcja ironii u stoików, a także wykluczenie z tej tradycji Sokratesa ironicznego. Aryston bowiem, wierny sokratyzmowi cynicznemu, dąży do marginalizacji elementów aporetyki obecnych w dialogach platońskich na rzecz Sokratesa moralisty i dogmatyka, zaczerpniętego raczej z pism Ksenofonta. Jako obiekt polemiki kształtuje się zatem interpretacja antytetyczna wobec sokratyzmu, właściwa Arkesilaosowi i jego zawłaszczeniu postaci Sokratesa w wersji sceptycznej.

Pod koniec omawianego zbioru Michel Narcy odnosi się do świadectwa Diogenesa Laertiosa o związkach Sokratesa z Eurypidesem („Socrate et Euripide. Le point de vue de Diogène Laërce", s. 321-332). Wbrew potocznej lekturze, która postrzega u Diogenesa Laertiosa II 18 rzekomą współpracę filozofa z tragikiem, co czyniłoby z Sokratesa postać mniej znaczącą, Narcy podkreśla, że cała ta sekwencja skierowana jest raczej na ukazanie wyższości intelektualnej filozofa. Jak wynika bowiem z dokładnej analizy kolejnych miejsc, Sokrates okazuje raczej jawną niezgodność z Eurypidesem (II 33). W swej subtelnej argumentacji Diogenes zmienia podany na wstępie sens znajomości Sokratesa z Eurypidesem na rzecz pewnej zależności tragika od autorytetu intelektualnego filozofa.

Tekst Aniello Montano, „In Memoriam di Mario Montuori” (s. 335-347), zamyka ten wielogłosowy dialog o Sokratesie i sokratykach. Pozycja ta stanowi niewątpliwie znaczący wkład oraz istotny punkt odniesienia dla tych, którzy zajmują się literaturą sokratejską, właśnie z powodu przedstawionego tu „pluralistycznego punktu widzenia w dyskusji”. Wydawcom i autorom przypada zasługa wdrożenia, w tej oraz poprzednich pracach, takiego ujęcia, które w komplementarności świadectw uznaje pewne wiążące narzędzie dla zrozumienia „zagadki” Sokratesa, a także łączy spojrzenie na sokratyków z ich rozległą twórczością literacką, przywracając w ten sposób cały kompleks kulturowy ukształtowany wokół tej postaci.

Refleksja uczonych na te tematy nie ogranicza się zresztą do omawianego tutaj opracowania. Konferencja zainicjowana pierwszym zjazdem w roku 2003 w Aix en Provence, 
której owocem był wolumen Xénophon et Socrate, znalazła swą twórczą kontynuację w konferencji w Senigallia (Socratica 2005), a także w seminarium w Palermo z roku 2006 (Il Socrate dei dialoghi). Przewidziana jest również trzecia edycja Socratica, planowana na koniec 2011 i początek 2012 r. Oczekujemy zatem dalszego wzbogacania panoramy studiów sokratejskich, które podążając w dotychczasowym kierunku, potwierdzają najnowszą tendencję, by nie uznawać jednego źródła za jakoś wyjątkowo uprzywilejowane. Strona www.socratica.eu, gdzie podane są informacje zarówno o poprzednich konferencjach, jak i o przyszłym spotkaniu w Paryżu, nosi znaczący tytuł: „Not Plato Alone!”.

Zjezyka wtoskiego ttumaczyt Marian Wesoty 